\title{
Tyrosine Phosphorylation of the NR2B Subunit of the NMDA Receptor in the Spinal Cord during the Development and Maintenance of Inflammatory Hyperalgesia
}

\author{
Wei Guo, Shiping Zou, Yun Guan, Tetsuya Ikeda, Michael Tal, Ronald Dubner, and Ke Ren \\ Department of Oral and Craniofacial Biological Sciences, Dental School and Program in Neuroscience, University of \\ Maryland, Baltimore, Maryland 21201-1586
}

The present study examined the levels of NMDA receptor NR2 subunit tyrosine phosphorylation in a rat model of inflammation and correlated it with the development of inflammation and hyperalgesia. Hindpaw inflammation and hyperalgesia were induced by intraplantar injection of complete Freund's adjuvant. Proteins from the spinal cord (L4-L5) were immunoprecipitated with anti-NR2A or anti-NR2B antibodies and used for subsequent analysis using 4G-10, a specific anti-phosphotyrosine antibody. Compared with naive rats, there was a rapid and prolonged increase in tyrosine phosphorylation of the NR2B, but not NR2A, subunit after inflammation. The increase in NR2B tyrosine phosphorylation was dependent on primary afferent drive because (1) the phosphorylation correlated with the temporal profile of inflammation and hyperalgesia, (2) shorterduration noxious stimulation produced a rapid and shorterlasting increase in phosphorylation, and (3) local anesthetic block of the injected paw reversibly blocked inflammation-

Inflammation and hyperalgesia are associated with activitydependent changes in the spinal cord (Dubner and Ruda, 1992), a process that may share common characteristics of synaptic plasticity in other neural systems (Malenka and Nicoll, 1999; Woolf and Salter, 2000; Ali and Salter, 2001). Convincing evidence demonstrates that the development of spinal hyperexcitability and persistent pain involves activation of NMDA receptors (Haley et al., 1990; Woolf and Thompson, 1991; Ren et al., 1992). Glutamate colocalizes with substance $P$ in primary afferent terminals (De Biasi and Rustioni, 1988) and is released into the spinal dorsal horn after activation of peripheral nociceptors (Sluka et al., 1994). Because there is a dramatic increase in primary afferent input after persistent noxious stimulation, synaptic activation of spinal NMDA receptors also increases. The increased NMDA receptor function is expressed as an increase in channel opening and may involve transcriptional, translational, and post-translational modulation. Despite extensive studies in this area, the cellular and molecular mechanisms underlying

Received Dec. 19, 2001; revised April 18, 2002; accepted April 19, 2002.

This work was supported by National Institutes of Health Grants DE11964, DE12757, and DA10275. We thank E. B. Wade for technical assistance and Drs. M. W. Salter and Y.-Q. Huang for advice on the project.

Correspondence should be addressed to Dr. K. Ren, Department of Oral and Craniofacial Biological Sciences, Room 5A26, 666 West Baltimore Street, Baltimore, MD 21201-1586. E-mail: kren@umaryland.edu.

M.T. is on sabbatical leave from the Department of Anatomy and Embryology, Hebrew University School of Medicine and Dentistry, P.O. Box 12272, Jerusalem 91120, Israel.

Copyright (C) 2002 Society for Neuroscience $\quad 0270-6474 / 02 / 226208-10 \$ 15.00 / 0$ induced NR2B tyrosine phosphorylation and delayed hyperalgesia. The increase in NR2B tyrosine phosphorylation was abolished by intrathecal pretreatment with genistein, a tyrosine kinase inhibitor; PP2, an Src family tyrosine kinase inhibitor; AIDA, a group I metabotropic glutamate receptor antagonist; L733,060, an NK1 tachykinin receptor antagonist, and chelerythrine, a protein kinase $\mathrm{C}$ inhibitor. In addition, intrathecal PP2 delayed the onset of mechanical hyperalgesia and allodynia. These findings correlate in vivo NMDA receptor tyrosine phosphorylation with the development and maintenance of inflammatory hyperalgesia and suggest that signal transduction upstream to NR2B tyrosine phosphorylation involves G-proteincoupled receptors and PKC and Src family protein tyrosine kinases.

Key words: AIDA; PP2; chelerythrine; tyrosine kinase; Freund's adjuvant; rat

NMDA receptor activation and their signal transduction after injury are still unclear.

Protein phosphorylation is a major mechanism for the regulation of receptor function. The native NMDA receptor is likely a tetramer that consists of two NR1 and two NR2 subunits (Laube et al., 1998). Phosphorylation of multiple sites in the cytoplasmic $\mathrm{C}$ termini of the NR1 and NR2 subunits is known to modulate NMDA receptor activity and affect synaptic transmission (Tingley et al., 1997; Lu et al., 2000a; Zou et al., 2000). Among the signal transduction pathways for NMDA receptor activation involving protein phosphorylation, tyrosine phosphorylation of the NR2 subunits plays a key role (Moon et al., 1994; Lau and Huganir, 1995; Xiong et al., 1999). NMDA receptor gating is closely regulated by tyrosine kinase Src (Yu et al., 1997; Xiong et al., 1999). It has been shown that the major tyrosinephosphorylated protein in the postsynaptic density is the NR2B subunit of the NMDA receptor (Moon et al., 1994). Tyrosine phosphorylation of the NR2 subunits, particularly the NR2B subunit, has been associated with long-term potentiation (LTP) (Rosenblum et al., 1996; Rostas et al., 1996), as well as neuropathological conditions (Menegoz et al., 1995; Dunah et al., 2000). There have been no reports on whether tyrosine phosphorylation of the NMDA receptor is associated with the development of persistent pain. Furthermore, there is no direct evidence that Src family tyrosine kinases participate in NR2B subunit receptor phosphorylation in model systems of activity-dependent plasticity (Ali and Salter, 2001).

NR2B immunoreactivity is localized to the rat spinal dorsal 
horn (Yung, 1998; Boyce et al., 1999), and protein tyrosine kinases are expressed in the spinal cord (Ross et al., 1988). In the present study, we produced inflammation and hyperalgesia in rats and examined the tyrosine phosphorylation of the spinal NR2 subunits in relation to the development and maintenance of hyperalgesia. We show that there was a prolonged increase in tyrosine phosphorylation of the NR2B subunit that was closely related to peripheral inflammation and hyperalgesia. The increased NR2B tyrosine phosphorylation occurred rapidly and was blocked by local anesthesia of the injured area, an Src family tyrosine kinase inhibitor, antagonists of G-protein-coupled receptors, and a protein kinase C (PKC) inhibitor. These findings correlate in vivo NMDA receptor tyrosine phosphorylation with the development and maintenance of inflammatory hyperalgesia and suggest upstream mediators involved in the signal transduction cascade leading to tyrosine phosphorylation.

Preliminary results of this study have been reported in abstract form (Guo et al., 2001).

\section{MATERIALS AND METHODS}

Animals. Adult male Sprague Dawley rats weighing 150-250 gm (Harlan, Indianapolis, IN) were used in all experiments. Rats were on a $12 \mathrm{hr}$ light/dark cycle and received food and water ad libitum. To produce inflammation and hyperalgesia, complete Freund's adjuvant (CFA; 0.2$0.3 \mathrm{ml} ; 0.1 \mathrm{mg}$ Mycobacterium tuberculosis; Sigma, St. Louis, MO) suspended in an oil-saline (1:1) emulsion was injected subcutaneously into one (behavioral and immunocytochemical studies) or two (immunoprecipitation and Western blot studies) hindpaws. The CFA injection produced an intense tissue inflammation of the hindpaw characterized by erythema, edema, and hyperalgesia (Iadarola et al., 1988; Hylden et al., 1989; Ren et al., 1992). The inflamed animals groom normally and display normal locomotor activity. They maintain their weight, explore their environment, and interact with other rats. Saline $(0.2-0.3 \mathrm{ml}, 0.9 \%)$ was used as a control for CFA injection. Mustard oil (allyl isothiocyanate) was applied to the plantar surface of the hindpaw via a $5 \times 5 \mathrm{~mm}$ gauze pad presoaked in mustard oil. The contact of the gauze with skin was limited to $20 \mathrm{sec}$. The application of mustard oil excites primary afferent $\mathrm{C}$-fiber and produces increased excitability of dorsal horn neurons and behavioral hyperalgesia (Woolf and King, 1990; Urban et al., 1996). Mustard oil as well as saline was used as shorter-lasting noxious stimuli compared with CFA. Naive rats were used as a control. The experiments were approved by the Institutional Animal Care and Use Committee of the University of Maryland Dental School.

Western blot and immunoprecipitation. Naive and treated rats (10 min to $14 \mathrm{~d}$ after CFA injection) were overdosed with pentobarbital sodium $(100 \mathrm{mg} / \mathrm{kg}$, i.p). To focus on the dorsal horn mechanisms of sensory processing, the dorsal half of the L4-L5 spinal cord tissues were removed and homogenized in solubilization buffer $(50 \mathrm{~mm}$ Tris- $\mathrm{HCl}, \mathrm{pH} 8.0 ; 150$ mu NaCl, 1 mm EDTA, $1 \%$ NP-40, $0.5 \%$ deoxycholic acid, $0.1 \%$ SDS, 1 $\mathrm{mM} \mathrm{Na}_{3} \mathrm{VO}_{4}, 1 \mathrm{U} / \mathrm{ml}$ aprotinin, $20 \mu \mathrm{g} / \mathrm{ml}$ leupetin, and $20 \mu \mathrm{g} / \mathrm{ml}$ pepstatin A). Some initial experiments used whole spinal cord tissue and obtained similar results on NR2 subunit tyrosine phosphorylation. The homogenate was centrifuged at $14,000 \mathrm{rpm}$ for $10 \mathrm{~min}$ at $4^{\circ} \mathrm{C}$. The supernatant was removed. The protein concentration was determined using a detergent-compatible protein assay with a bovine serum albumin as standard. Each sample contained proteins from one animal. Proteins $(50 \mu \mathrm{g})$ were separated on a 7.5\% SDS-PAGE gel and blotted to nitrocellulose membrane (Amersham Biosciences, Arlington Heights, IL) with a Trans-Blot Transfer Cell system (Bio-Rad, Hercules, CA). The blots were blocked with $5 \%$ milk in TBS buffer $(20 \mathrm{~mm}$ Tris, $150 \mathrm{~mm}$ $\mathrm{NaCl}, \mathrm{pH}$ 7.4) at room temperature for $30 \mathrm{~min}$. After decanting the blocking buffer, the blot was incubated with the respective antibody overnight at $4^{\circ} \mathrm{C}$. The membrane was washed with TBS buffer and incubated for $1 \mathrm{hr}$ with anti-goat IgG horseradish peroxidase (1:3000; Santa Cruz Biotechnology, Santa Cruz, CA) in 5\% milk and TBS. The membrane was then washed three times with TBS buffer. The immunoreactivity was detected using Enhanced Chemiluminescence (ECL; Amersham).

For immunoprecipitation, the samples were incubated with NR2A or NR2B antiserum (Santa Cruz Biotechnology) overnight and then with protein A/G-Sepharose beads (Santa Cruz Biotechnology). To verify the specificity of NR2A and NR2B antibodies, some samples were boiled for $5 \mathrm{~min}$ before immunoprecipitation to separate associated proteins. Similar results were obtained in samples after boiling except the elimination of proteins coimmunoprecipitated with NR2A or NR2B subunits. SDS sample buffer $(0.05 \mathrm{ml})$ was added to elute NR2A or NR2B subunit from the protein $\mathrm{A} / \mathrm{G}$ beads. The eluant was separated on SDS-polyacrylamide gel $(7.5 \%)$, and transferred to a nitrocellulose membrane. The membranes were blocked and incubated with anti-phosphotyrosine 4G-10 (1:1000; Upstate Biotechnology, Lake Placid, NY) and further washed and incubated with anti-mouse IgG horseradish peroxidase (1:3000), and ECL was performed. To control for protein loading and transfer efficiency, the membranes were stripped and then reprobed with NR2A or NR2B antiserum (1:1000) after the first round of analysis. The NR2A and NR2B subunit levels were also analyzed with Western blot without immunoprecipitation. The loading and blotting of equal amount of proteins were verified with Coomassie blue staining.

ECL-exposed films were digitalized, and densitometric quantification of immunoreactive bands was performed using Scion NIH Image 1.60. The relative tyrosine-phosphorylated protein levels were obtained by normalizing the anti-phosphotyrosine immunoblot against the corresponding NR2 subunit immunoblot from the same membrane. ANOVA and unpaired two-tailed $t$ test were used to determine significant differences between sample groups. $p<0.05$ was considered significant in all cases.

Quantification of inflammation. Evans' blue dye extravasation was examined to quantify CFA-induced inflammation. Evans' blue dye (50 $\mathrm{mg} / \mathrm{kg}, 2 \%$ solution) was injected through the tail or femoral vein at the end of the experiments. The rats were killed 10 min later. To quantify the extravasated Evans' blue, the hindpaw tissues were dissected, weighed and cut into small blocks. The tissues were then incubated overnight in a 7:3 mixture of acetone and $35.2 \mathrm{~mm}$ sodium sulfate solution (v/v) at room temperature with intermittent shaking. After incubation, samples were centrifuged at $10,000 \mathrm{rpm}$ for $20 \mathrm{~min}$, and the supernatant was separated. The absorbance of this supernatant at $620 \mathrm{~nm}$ was determined in a spectrophotometer. The recovery of the extravasated dye per gram weight of tissue (micrograms per gram) was calculated by comparing the absorbency of the supernatant with a standard curve. The standard curve was generated from a series of the same extraction solution mixed with known amounts of Evans' blue dye.

Intrathecal procedure. The intrathecal cannulation was performed under methohexital anesthesia $(50 \mathrm{mg} / \mathrm{kg}$, i.p.). The atlanto-occipital membrane was exposed, and a 7.0-8.0 cm length of PE-10 tubing was inserted into the subarachnoid space through a slit made in the membrane. The cannula was advanced to the level of the lumbar spinal cord (Yaksh and Rudy, 1976). During recovery from anesthesia, animals were examined for gross signs of motor impairment. Such animals were excluded from the study. The location of the distal end of the intrathecal catheter was verified visually after laminectomy at the end of the experiments. All the receptor antagonists and enzyme inhibitors were purchased from Research Biochemicals (Natick, MA) or Sigma unless otherwise indicated. The following agents were administered intrathecally: 5,7-dihydroxy-3(4-hydroxyphenyl)-4H-1-benzopyran-4-one; 4',5,7-trihydroxy-isoflavone, tyrosine kinase inhibitor (genistein); 1-aminoindan-1,5-dicarboxylic acid, group I metabotropic glutamate receptor (mGluR)-selective (AIDA), 3-[[3,5-bis(trifluoromethyl)phenyl]methoxy]-2-phenyl-piperidine, NK1 tachykinin receptor-selective (L-733,060 hydrochloride), 1,2-dimethoxy12-methyl-[1,3]benzodioxolo[5,6-c]phenanthridinium chloride, selective PKC inhibitor (chelerythrine chloride) (Calbiochem, La Jolla, CA), and [4-amino-5-(4-chlorophenyl)-7-( $t$-butyl)pyrazolo[3,4-D]pyrimidine, Src family protein tyrosine kinase inhibitor (PP2) (Calbiochem). 4-amino-7phenylpyrazol[3,4-D]pyrimidine (PP3) (Calbiochem), a negative control for PP2, and 7-O- $\beta$-D-glucopyranoside (genistin) (Calbiochem), an inactive analog of genistein, were also used. The drug vehicle saline (for AIDA and chelerythrine) or dimethylsulfoxide (DMSO; Sigma; for genistein, genistin, L-733,060, PP2, and PP3) was used as a control for intrathecal agents.

Behavioral testing. A unilateral hindpaw inflammation was produced. Complete Freund's adjuvant $(0.2 \mathrm{ml})$ suspended in an oil-saline (1:1) emulsion was injected into the lateral edge of one hindpaw subcutaneously. A set of calibrated Semmes-Weinstein (S-M) monofilaments (von Frey filaments; Stoelting, Kiel, WI) were used to deliver mechanical stimulation. The bending force of the filaments was in a range of $9 \mathrm{mg}$ to $257 \mathrm{gm}$. The testing method is described in detail elsewhere (Ren, 1999). Briefly, rats were habituated to stand on their hindpaws and lean against the experimenter's hand covered by a regular leather work glove. The testing filament was probed against the lateral edge of the hindpaw. The 
starting filament was the number 10 filament $(3.24 \mathrm{gm})$ against the normal skin and the number 5 filament $(0.19 \mathrm{gm})$ against the inflamed tissue. The filaments were applied in an ascending series. A descending series of the filaments were used when the rat responded to the starting filament. Each filament was tested five times at an interval of a few seconds. If paw withdrawal caused by stimulation was observed, it was registered as a response to a filament. Response threshold is defined as the lowest force of two or more consecutive von Frey filaments that produces at least two responses to each filament. A reduction in threshold suggests the development of allodynia, a nociceptive response to a normally non-noxious stimulus. An increase in response frequency, particularly to suprathreshold von Frey filaments, indicates mechanical hyperalgesia. The mechanical threshold data are presented as median with 25 and 75 percentiles. Nonparametric analyses (Kruskal-Wallis and Mann-Whitney $U$ ) were used for statistical comparisons. $p<0.05$ was considered statistically significant.

\section{RESULTS}

\section{Inflammation induced a prolonged increase in tyrosine} phosphorylation of the NR2B subunit

Our preliminary Western blot analysis indicated that inflammation did not induce changes in NR2A and NR2B subunit protein levels within a $7 \mathrm{~d}$ period (data not shown; but see Figs. 1-4). We then asked whether there was a change in the functional status of the receptor, specifically, a change in tyrosine phosphorylation of the NR2 subunits after inflammation. We examined both NR2A/2B subunits because they both are involved in synaptic plasticity and undergo tyrosine phosphorylation (Ali and Salter, 2001). The lumbar spinal cord tissues were collected from noninflamed naive rats and rats at $10 \mathrm{~min}$ to $14 \mathrm{~d}$ after injection of CFA. This time course was chosen based on previous studies that hindpaw inflammation starts as early as 10 min after injection of another inflammatory agent, carrageenan (Van Arman et al., 1965), and CFA-induced hyperalgesia lasts for 2 weeks (Iadarola et al., 1988; Ren, 1999).

To examine tyrosine phosphorylation of the NR2 subunits, L4 and L5 spinal cord protein samples were first immunoprecipitated with anti-NR2A and anti-NR2B antibodies. The eluted NR2A or NR2B proteins were then incubated with an anti-phosphotyrosine antibody, 4G-10. The tyrosine phosphorylation, as indicated by the immunoblot against 4G-10, was associated with a band of $180 \mathrm{kDa}$ (Fig. $1 A$, for PY-NR2B) (data not shown for NR2A). There was an increase in the intensity of the $4 \mathrm{G}-10$ bands after immunoprecipitation with anti-NR2B antibodies after inflammation compared with naive noninflamed rats (Fig. $1 A$ ). In contrast, there was no change in NR2B immunobands when the membranes were reprobed (Fig. 1A), consistent with the previous analysis that a change at the translation level was not detected by Western blot.

For quantification of $4 \mathrm{G}-10$ binding to the $180 \mathrm{kDa}$ band, each $4 \mathrm{G}-10$ band was normalized to the respective NR2A or NR2B immunoband after reprobing the same membrane against NR2A and NR2B antibodies. Inflammation produced a significant increase in NR2B tyrosine phosphorylation over time when compared with naive rats (ANOVA; $F=5.48 ; p=0.05 ; n=5$ ). The increase in NR2B tyrosine phosphorylation started as early as 10 $\min (183 \pm 22 \%$ of control; $p<0.05)$ and was maintained for at least $3 \mathrm{~d}(184 \pm 21$ to $234 \pm 27 \% ; p<0.05)$ after the injection of CFA. In some experiments, when rats were killed almost immediately (2-5 min) after injection of CFA, there was also an increase in NR2B tyrosine phosphorylation (data not shown). At 7 and $14 \mathrm{~d}$ after inflammation, the levels of NR2B tyrosine phosphorylation $(7 \mathrm{~d}, 129 \pm 11 \%$ of control, $p=0.33 ; 14 \mathrm{~d}, 114 \pm$ $18 \%$ of control, $p=0.44)$ were still higher than the control, although the difference did not reach statistical significance (Fig.
$1 B)$. In contrast, there were no changes in NR2A tyrosine phosphorylation after inflammation (data not shown).

\section{Tyrosine phosphorylation and the development of inflammation and hyperalgesia}

Previous studies have demonstrated hyperalgesia and allodynia after hindpaw inflammation (Hargreaves et al., 1988; Iadarola et al., 1988; Ren, 1999), but the early development of persistent inflammatory pain has not been described. We examined the early time course of inflammation and hyperalgesia and compared it with the temporal profile of NR2B tyrosine phosphorylation. We used von Frey filaments to evaluate the paw withdrawal threshold before and shortly after the injection of CFA. As shown in Figure $1 C$, the mechanical response threshold of the rat started to decrease as soon as 2 min after the injection of CFA. Within 10 min after CFA, the mean median mechanical threshold was reduced from 62.9 to $1.1 \mathrm{gm}$ (interquartile range, $0.6-8.18 \mathrm{gm}$ ) $(p<0.0001 ; \mathrm{n}=6)$, indicating mechanical allodynia (nocifensive behavior in response to an innocuous stimulus). In addition to a reduction of mechanical threshold, the rats exhibited exaggerated responses to probing with high-intensity ( $>10 \mathrm{gm})$ filaments (data not shown), indicating the presence of mechanical hyperalgesia. These results indicate a rapid development of mechanical hyperalgesia and allodynia. A rapid development of thermal hyperalgesia at $10 \mathrm{~min}$ after CFA injection has also been shown recently (Ji et al., 2002). The decrease in mechanical threshold was maintained throughout the $2 \mathrm{hr}$ testing period. The inflammationinduced mechanical hyperalgesia and allodynia has been shown to persist for 7-14 d after inflammation (Ren, 1999). There was no change in mechanical threshold of the contralateral paw (Fig. 1C).

The CFA-induced inflammation was verified by using Evans' blue extravasation into peripheral tissues as a measure of inflammation and activation of peripheral nociceptors (Imbe et al., 2001). The time course of Evans' blue extravasation after CFA injection paralleled NR2B tyrosine phosphorylation (Fig. 1D) and inflammatory hyperalgesia for early time points shown in Figure 1 and later time points in previous studies (Ren, 1999). These results suggested that NR2B tyrosine phosphorylation was closely associated with the development of peripheral inflammation and hyperalgesia.

\section{Effects of short-duration noxious stimulation}

To confirm the rapid occurrence of NR2B tyrosine phosphorylation and its correlation with the time course of peripheral inflammation and hyperalgesia after hindpaw stimulation, we investigated the effects of saline injection and mustard oil application to the hindpaw. Although the saline injection can be used as a control for CFA, the needle insertion and the injection volume are a transient noxious stimulus. Mustard oil has been routinely used to activate small caliber nociceptive primary afferent fibers. The stimulating effect of mustard oil lasts from 30 min to a few hours (Woolf and King, 1990).

As shown in Figure 2, $A$ and $B$, saline produced a transient increase in NR2B tyrosine phosphorylation at $10 \mathrm{~min}$ after injection $(p<0.01 ; n=3)$. The effect of saline injection on tyrosine phosphorylation was resolved within $30 \mathrm{~min}$ (data not shown). The NR2B tyrosine phosphorylation remained at control levels from 2 hr to $3 \mathrm{~d}$ after saline injection (Fig. $2 A, B$ ). Consistently, there was a transient reduction of mechanical response threshold at 5-10 min after saline injection ( $p<0.01 ; n=6)$ (Fig. $2 C$ ). Mustard oil also produced an increase in NR2B tyrosine phosphorylation that lasted for $5 \mathrm{hr}$ (Fig. $3 A, B$ ). The Evans' blue 

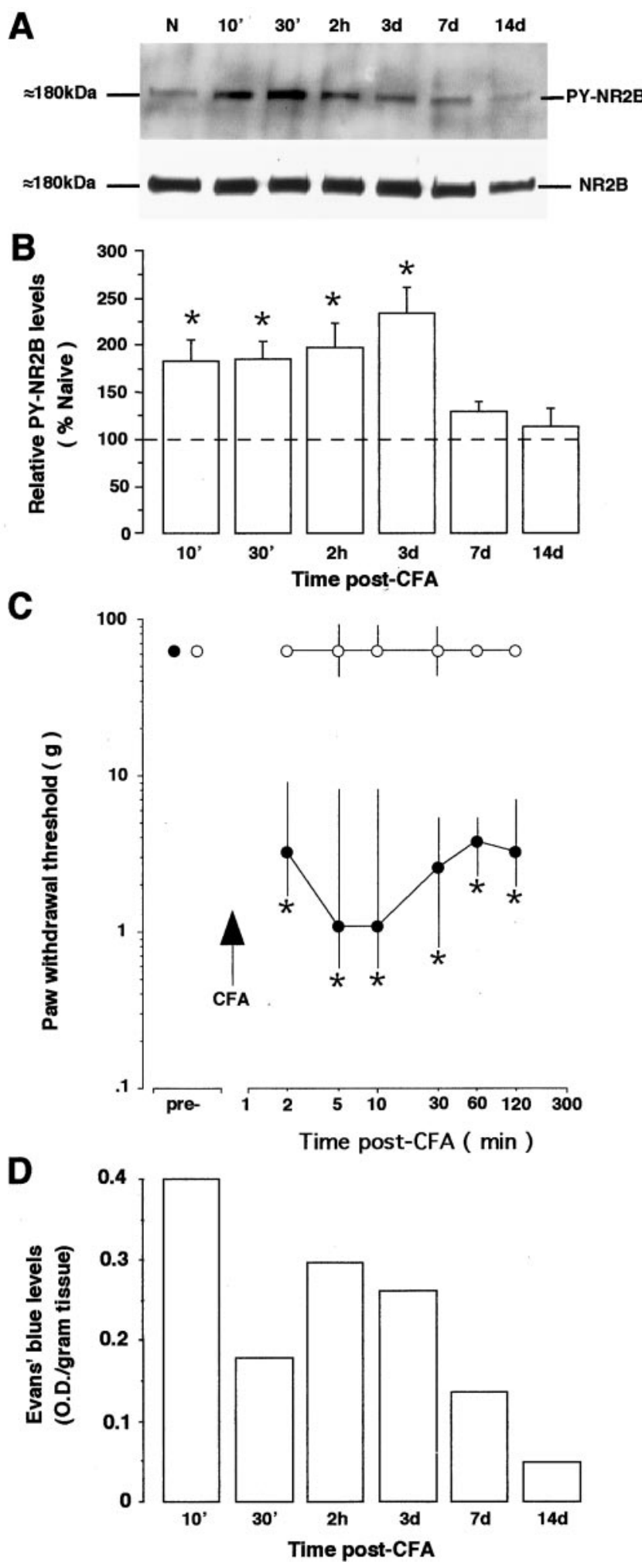

Figure 1. Rapid and prolonged enhanced tyrosine phosphorylation of the NR2B subunits and the development of inflammatory hyperalgesia after hindpaw inflammation in vivo. Proteins were extracted from L4-L5 spinal cord of noninflamed naive $(N)$ rats and rats at $10 \mathrm{~min}\left(10^{\prime}\right)$ to $14 \mathrm{~d}$ after inflammation. $A$, The top blot shows the immunoreactive bands against anti-phosphotyrosine 4G-10 (PY-NR2B) after immunoprecipitation of extracted proteins with anti-NR2B antibodies. The bottom blot in $A$ shows immunobands against NR2B antibodies after stripping and reprobing the same membrane previously probed with $4 \mathrm{G}-10$ antibodies. $B$, Comparison of the levels of tyrosine phosphorylation normalized to extravasation after mustard oil increased sharply at $10 \mathrm{~min}$, gradually resolved in 2-5 hr, and returned to control level at $24 \mathrm{hr}$ after stimulation (Fig. $3 C$ ). The finding that the levels of NR2B tyrosine phosphorylation were maintained for $10 \mathrm{~min}$ to $5 \mathrm{hr}$, whereas the Evans' blue extravasation attenuated rapidly after 10 min, suggests that tyrosine phosphorylation may outlast the mustard oil-induced inflammation.

\section{NR2B tyrosine phosphorylation is dependent on primary afferent input}

The above results strongly suggest that tyrosine phosphorylation of the NR2B subunit is dependent on the development and persistence of peripheral nociceptor activation. We produced local anesthetic block to test this hypothesis directly. A local anesthetic, lidocaine $(2 \%, 0.3 \mathrm{ml})$, was injected subcutaneously into the rat hindpaw before the injection of CFA. Ten minutes after the infiltration of lidocaine, CFA was injected into the same site to produce inflammation. In rats pretreated with saline $(0.9 \%, 0.3 \mathrm{ml})$, the NR2B tyrosine phosphorylation was increased by $339 \pm 49 \%(p<0.05)$ and $291 \pm 23 \%(p<0.05)$ of control at 10 and $30 \mathrm{~min}$ after CFA injection. In lidocaine-treated rats, the increase in NR2B tyrosine phosphorylation was abolished at $10 \min (76 \pm 10 \%$ of control; $p>0.05)$ and $30 \min (108 \pm 20 \%$ of control; $p>0.05)$ after CFA injection ( $n=4$ per time point) (Fig. $4 A, B$ ). The lidocaine treatment similarly blocked the early development of mechanical allodynia (Figs. $1 C, 4 C$ ). In lidocainetreated rats $(n=6)$, the reduction of mechanical response threshold was delayed until $1 \mathrm{hr}$ after the injection of CFA (Fig. 4C). The NR2B tyrosine phosphorylation appeared at $2 \mathrm{hr}$ after inflammation (Fig. 4A,B), when the local anesthesia had worn off (Fig. $4 C$ ). Local anesthetic treatment after the injection of CFA produced similar blocking effects on NR2B tyrosine phosphorylation $(n=4)$ and mechanical allodynia $(n=5)$ (data not shown). These findings indicate that peripheral nociceptor activation evoked by inflammation is necessary for the maintenance of hyperalgesia and allodynia.

$\leftarrow$

NR2B-immunoreactive bands. The relative phosphotyrosine protein levels $($ mean \pm SEM) after inflammation are expressed as a percentage of the naive $(N)$ controls for the purpose of illustration. Raw data were used for statistical comparisons. Asterisks indicate significant differences $(p<$ $0.05)$ from the naive controls. $N=5$ per time point. Dashed line indicates the control levels in noninflamed rats. $C$, Changes in mechanical response threshold of the hindpaw of the rat after CFA injection. The mechanical response threshold were determined with von Frey microfilaments and are shown by filled circles (injected paw) and open circles (noninjected paw). Data are presented as median with interquartile ranges ( 75 percentile, upward bars; 25 percentile, downward bars). There was a rapid reduction of the response threshold at $10 \mathrm{~min}$ after CFA injection that lasted throughout the $2 \mathrm{hr}$ testing period. The early, rapid changes in mechanical response threshold correspond to the time course of NR2B tyrosine phosphorylation $(A, B)$. The threshold of the noninjected paws remained unchanged. The asterisks indicate significant differences versus pre-CFA value $(p<0.05 ; n=6)$. A $\log$ scale is used. $D$, Evans' blue dye extravasation was examined to verify inflammation of the CFA-injected hindpaw. The dye $(5 \mathrm{mg} / \mathrm{kg} ; 0.2 \%)$ was injected intravenously $10 \mathrm{~min}$ before the animals were killed. The hindpaw tissue was dissected, weighed, and cut into small blocks. The tissues were incubated overnight in a mixture of acetone and sodium sulfate solution. The samples were then centrifuged, and the supernatant was separated. The absorbency of the supernatant at $620 \mathrm{~nm}$ was determined in a spectrophotometer. The results are expressed as the OD value per gram tissue $(n=1-2$ per time point). The extravasation Evans' blue was nondetectable in nontreated animals. The levels of NR2B subunit tyrosine phosphorylation paralleled the time course of CFA-induced tyrosine phosphorylation, as indicated by Evans' blue extravasation. 
A

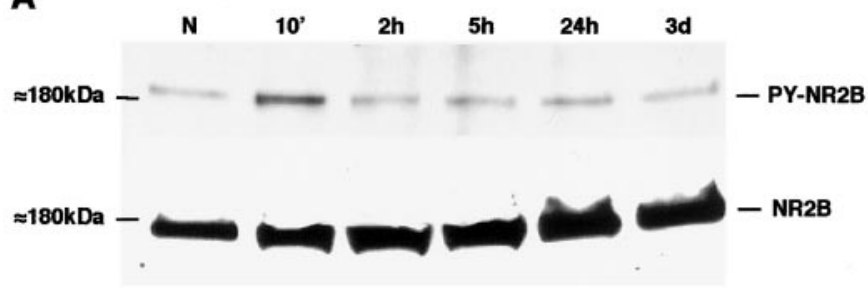

B

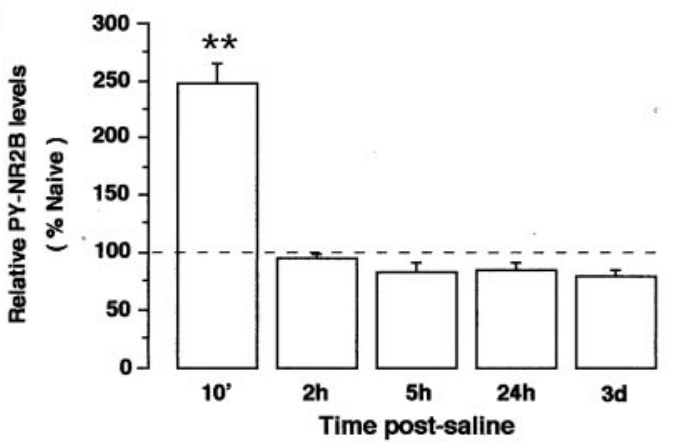

C

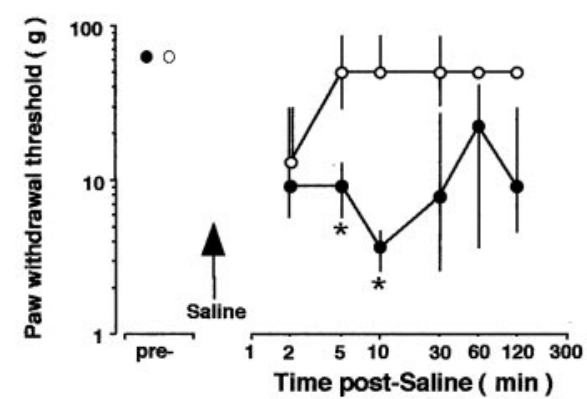

Figure 2. Effect of short-duration stimulation on NR2B tyrosine phosphorylation. Saline was injected into the intraplantar surface of the hindpaw $(0.9 \% ; 0.3 \mathrm{ml})$. $A$, The top blot shows the immunoreactive bands against anti-phosphotyrosine 4G-10 (PY-NR2B). The bottom blot shows immunobands against NR2B antibodies on the same membrane. The same immunoprecipitation and Western blot procedures were used as described in Figure 1. There was a transient increase in the intensity of PY-NR2B band at $10 \mathrm{~min}\left(10^{\prime}\right)$ after saline injection. $B$, Summary of the relative levels of tyrosine phosphorylation normalized to respective NR2B-immunoreactive bands. ${ }^{* *} p<0.01$ versus noninjected rats. $N=3$ per group. $C$, Changes in mechanical response threshold of the hindpaw after saline injection. The mechanical response thresholds were determined with von Frey microfilaments and shown by filled circles (injected paw) and open circles (noninjected paw), respectively. Data are presented as median with interquartile ranges ( 75 percentile, upward bars; 25 percentile, downward bars). There was a transient decrease in von Frey threshold at 5-10 min after injection, corresponding to the transient increase in tyrosine phosphorylation shown in $A$. ${ }^{*} p<0.05$ versus presaline controls $(n=6)$.

\section{Contribution of protein tyrosine kinases}

To verify the involvement of protein tyrosine kinase in NR2B tyrosine phosphorylation, animals were pretreated intrathecally with a tyrosine kinase inhibitor, genistein, at $10 \mathrm{~min}$ before injection of CFA. Although a lower dose $(0.05 \mathrm{mg} ; n=3)$ did not produce an effect, genistein at $0.1 \mathrm{mg}(n=6)$ resulted in an attenuation of inflammation-induced tyrosine phosphorylation of the NR2B band ( $p>0.05$ vs naive rats) (Fig. $5 A, B$ ). The protein tyrosine kinase that regulates NMDA receptor function is a member of the Src family (Yu et al., 1997). We then showed that intrathecal administration of PP2 $(0.003 \mathrm{mg} ; \mathrm{n}=3)$, a selective
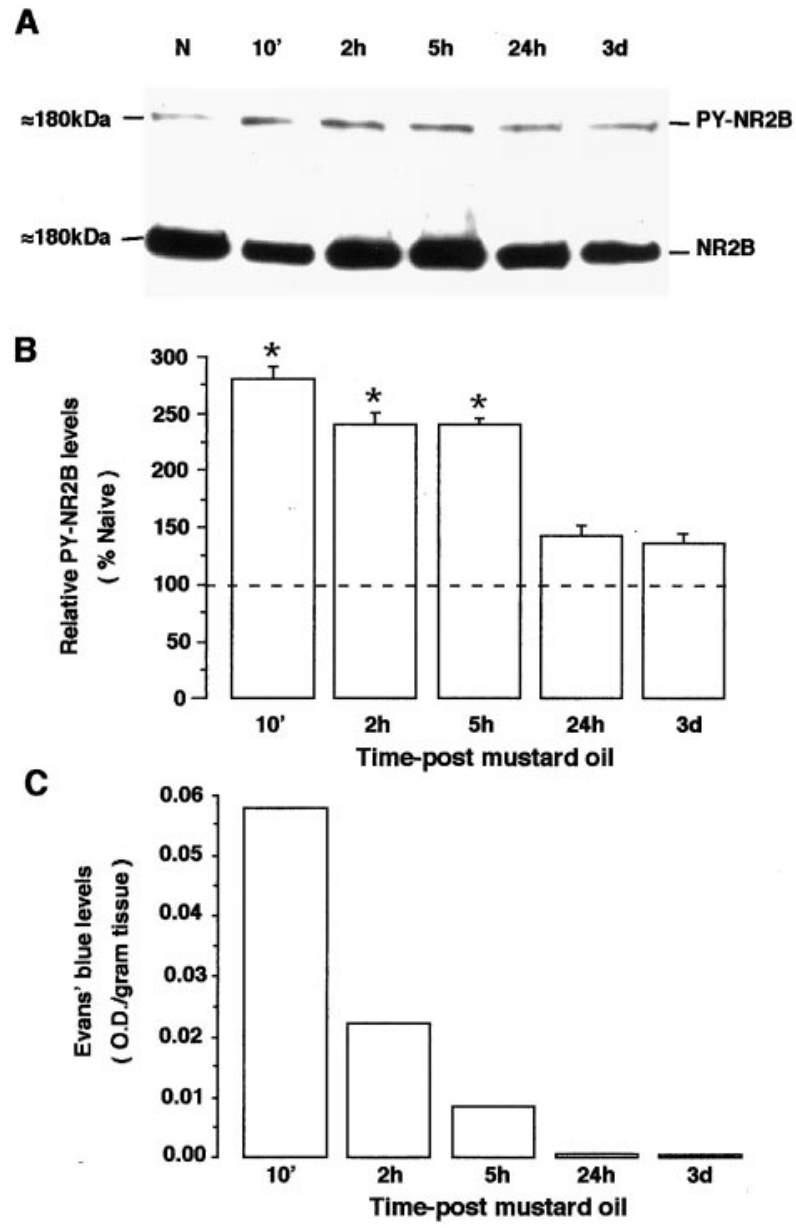

Figure 3. Effect of short-duration stimulation on NR2B tyrosine phosphorylation. Mustard oil, a small fiber irritant, was applied topically to the hindpaw via a gauze pad $(5 \times 5 \mathrm{~mm})$ for $20 \mathrm{sec} . A$, Representative immunoreactive blot for anti-phosphotyrosine 4G-10 (PY-NR2B) and NR2B. The same immunoprecipitation and Western blot procedures were used as described in Figure 1. B, Comparison of the levels of tyrosine phosphorylation normalized to NR2B-immunoreactive bands. The relative phosphotyrosine protein levels after inflammation are expressed as a percentage of the naive $(N)$ controls. ${ }^{*} p<0.05$ versus naive controls. $N=3$ per time point. Dashed line indicates the control levels in naive rats. There was an increase in tyrosine phosphorylation between 10 min to $5 \mathrm{hr}$ after mustard oil application. $C$, Hindpaw Evans' blue dye extravasation after mustard oil application. The extravasation of Evans' blue was nondetectable in nontreated animals. After mustard oil application, the dye extravasation sharply increased at $10 \mathrm{~min}$ and gradually returned to the control level at $24 \mathrm{hr} . N=1-2$ per time point.

Src family tyrosine kinase inhibitor, abolished inflammationinduced NR2B tyrosine phosphorylation ( $p>0.05$ vs naive rats) (Fig. $6 A, B)$. The intrathecal pretreatment with genistin $(0.1 \mathrm{mg}$; $n=3)$, an inactive analog of genistein, and PP3 (0.003 mg; $n=3)$, a negative control for PP2, did not prevent inflammation-induced increase in NR2B tyrosine phosphorylation (data not shown).

PP2, when injected intrathecally $(0.003 \mathrm{mg} ; \mathrm{n}=5) 10 \mathrm{~min}$ before injection of CFA, also delayed the reduction of mechanical response threshold after inflammation when compared with vehicle-treated (DMSO; $n=4$ ) rats (Fig. 6C). The effect of PP2 on mechanical hyperalgesia and allodynia lasted for $\sim 20 \mathrm{~min}$. When PP2 (0.003 mg; $n=8)$ was injected at $5 \mathrm{hr}$ after CFA, there was an increase in median mechanical threshold from 5.6 to 8.8 gm at 5 min after PP2 $(p<0.05)$ (Fig. $6 D)$. The effect of PP2 
A

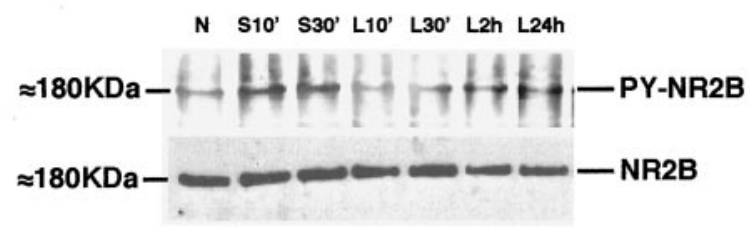

B

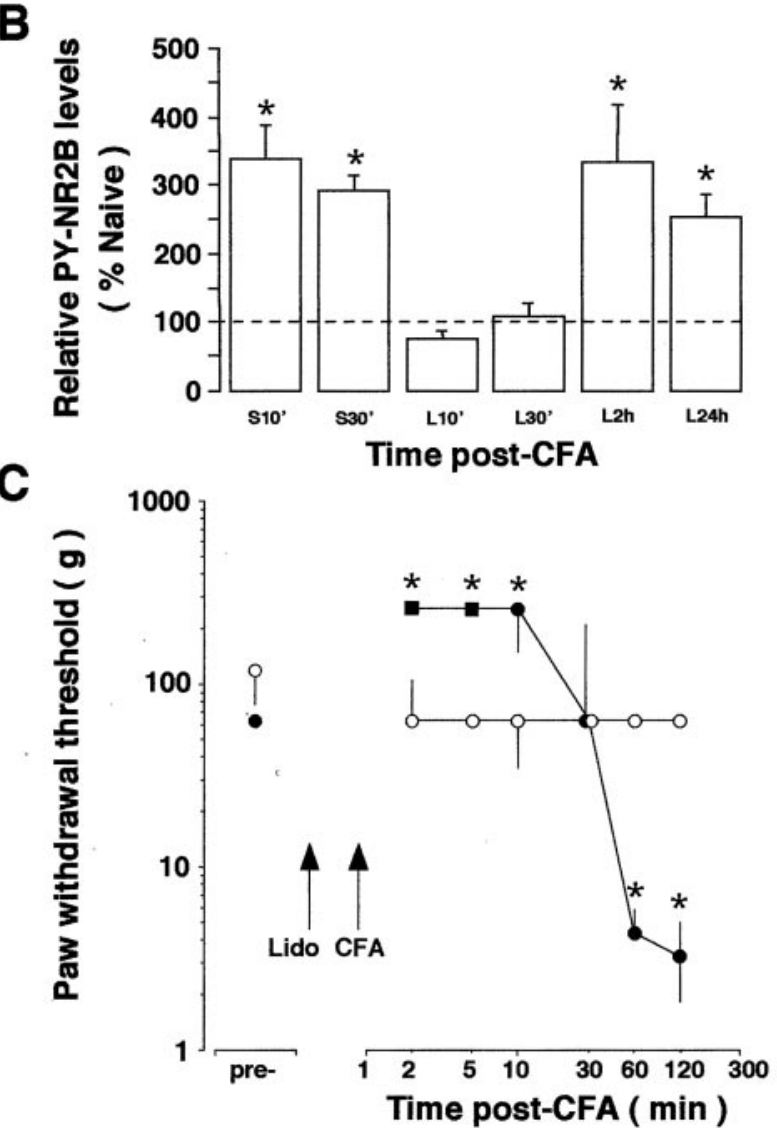

Figure 4. The effect of preemptive local anesthesia on inflammationinduced increase in NR2B tyrosine phosphorylation. Lidocaine $(0.3 \mathrm{ml}$; $2 \%$ ) was injected into the plantar surface $10 \mathrm{~min}$ before CFA injection into the same hindpaw site. Saline $(0.3 \mathrm{ml} ; 0.9 \%)$ was injected as a control for lidocaine in other animals. $A$, Examples of immunoreactive bands for anti-phosphotyrosine 4G-10 (PY-NR2B) and NR2B. The same immunoprecipitation and Western blot procedures were used as described in Figure 3. $S 10^{\prime}, S 30^{\prime}, 10$ and $30 \mathrm{~min}$ after CFA injection in rats pretreated with intraplantar saline. $L 10^{\prime}-L 24 h, 10 \mathrm{~min}$ to $1 \mathrm{~d}$ after CFA injection in rats pretreated with lidocaine. $B$, Summary of the effect of lidocaine on inflammation-induced NR2B tyrosine phosphorylation. In lidocainetreated rats, the increase in tyrosine phosphorylation was blocked at 10-30 min after CFA injection and reappeared at $2 \mathrm{hr}$ time point later. ${ }^{*} p<0.05$ versus naive rats. $N=4$ per time point. $C$, CFA-induced reduction of mechanical response threshold was reversibly blocked by lidocaine pretreatment. The von Frey threshold is shown by filled circles (inflamed paws) and open circles (noninflamed paws). Filled squares indicate nonresponders that did not respond to the von Frey filament of the highest intensity (257 gm). Data are presented as median with interquartile ranges (75 percentile, upward bars; 25 percentile, downward bars). Note the reappearance of mechanical allodynia at 1-2 hr after CFA injection. ${ }^{*} p<0.05 ; n=6$.

post-treatment on mechanical threshold was transient and lasted for $\sim 10 \mathrm{~min}$. These results indicate the involvement of the Src family tyrosine kinases in the development of dorsal horn hyperexcitability after hindpaw inflammation.
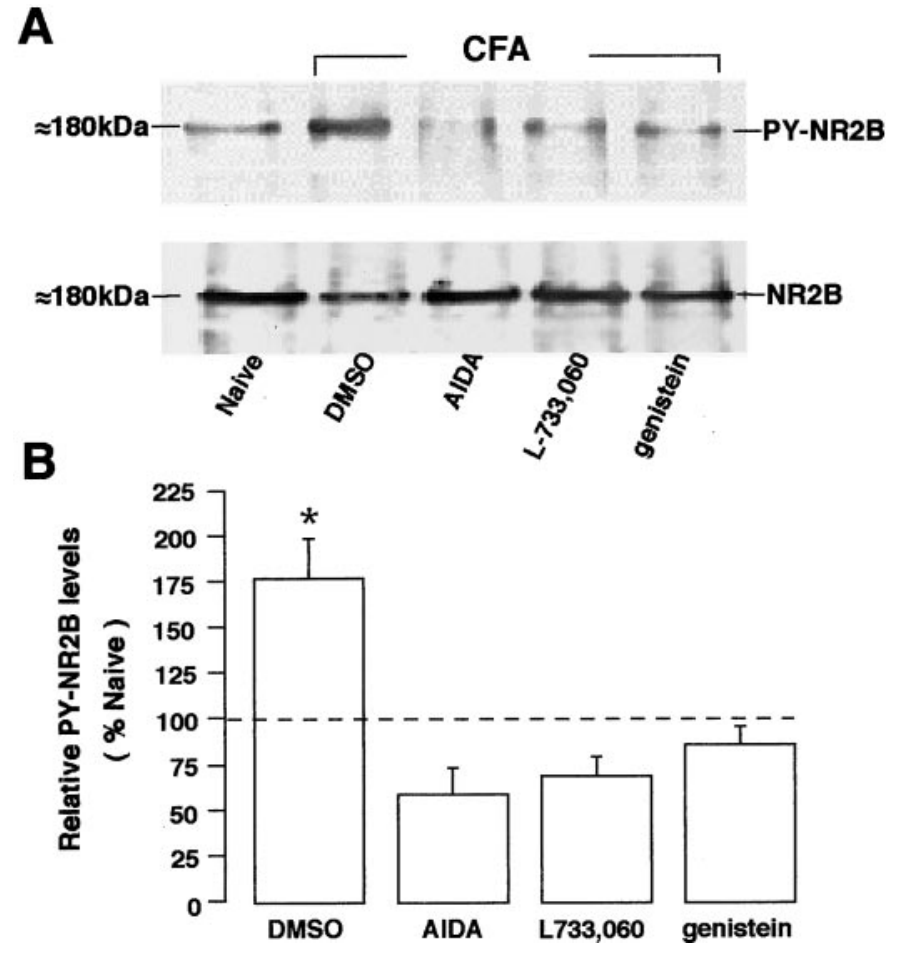

Figure 5. The effect of receptor antagonists and a tyrosine kinase inhibitor on inflammation-induced tyrosine phosphorylation of NR2B. The following drugs were administered: AIDA $(0.05 \mathrm{mg} ; n=6)$, a group I mGluR antagonist, L-733,060 (0.1 mg; $n=5)$, an NK1 tachykinin receptor antagonist, and genistein $(0.1 \mathrm{mg} ; n=6)$, a protein tyrosine kinase inhibitor. The drug vehicle, DMSO $(0.01 \mathrm{ml})$, was used as a control. All drugs were injected intrathecally $10 \mathrm{~min}$ before injection of CFA. $A$, Representative immunoblots against anti-4G-10 (PY-NR2B) and antiNR2B (bottom) antibodies. B, Mean relative levels of tyrosinephosphorylated NR2B proteins from three or four individual experiments. Dashed line in $B$ indicates the control level. ${ }^{*} p<0.05$ versus naive rats.

\section{The increased NR2B tyrosine phosphorylation is linked to G-protein-coupled receptors and protein kinase C mechanisms}

The Src family tyrosine kinases are activated by the proline-rich tyrosine kinase 2 (PYK2)/cell-adhesion kinase $\beta(\mathrm{CAK} \beta)$ pathway (Dikic et al., 1996). The PYK2/CAK $\beta$ pathway is sensitive to an increase in intracellular calcium (for review, see Girault et al., 1999). We examined the possibility that enhanced tyrosine phosphorylation is initiated through G-protein-coupled receptors, the activation of which leads to an increase in intracellular calcium. The rats were pretreated (at $10 \mathrm{~min}$ before injection of CFA) intrathecally with AIDA, a selective mGluR1 receptor antagonist; or L-733,060, a selective NK1 tachykinin receptor antagonist. The rats were killed at $30 \mathrm{~min}$ after injection of CFA. Compared with vehicle-treated rats, AIDA (0.05 mg; $n=6)$ and L-733,060 $(0.1 \mathrm{mg} ; \mathrm{n}=5)$ abolished NR2B tyrosine phosphorylation after inflammation ( $p>0.05$ vs naive rats) (Fig. $5 A, B)$. A lower dose of AIDA $(0.025 \mathrm{mg} ; n=3)$ did not produce an effect on NR2B tyrosine phosphorylation.

Recent in vitro studies indicate that mGluR1-mediated potentiation of NMDA receptor involves intracellular calcium and PKC (Skeberdis et al., 2001). Consistently, PKC activation induces NR2 tyrosine phosphorylation in the rat hippocampus (Grosshans and Browning, 2001). We examined the involvement of PKC in inflammation-induced NR2B tyrosine phosphorylation. Using the same intrathecal protocol (see above), the in- 

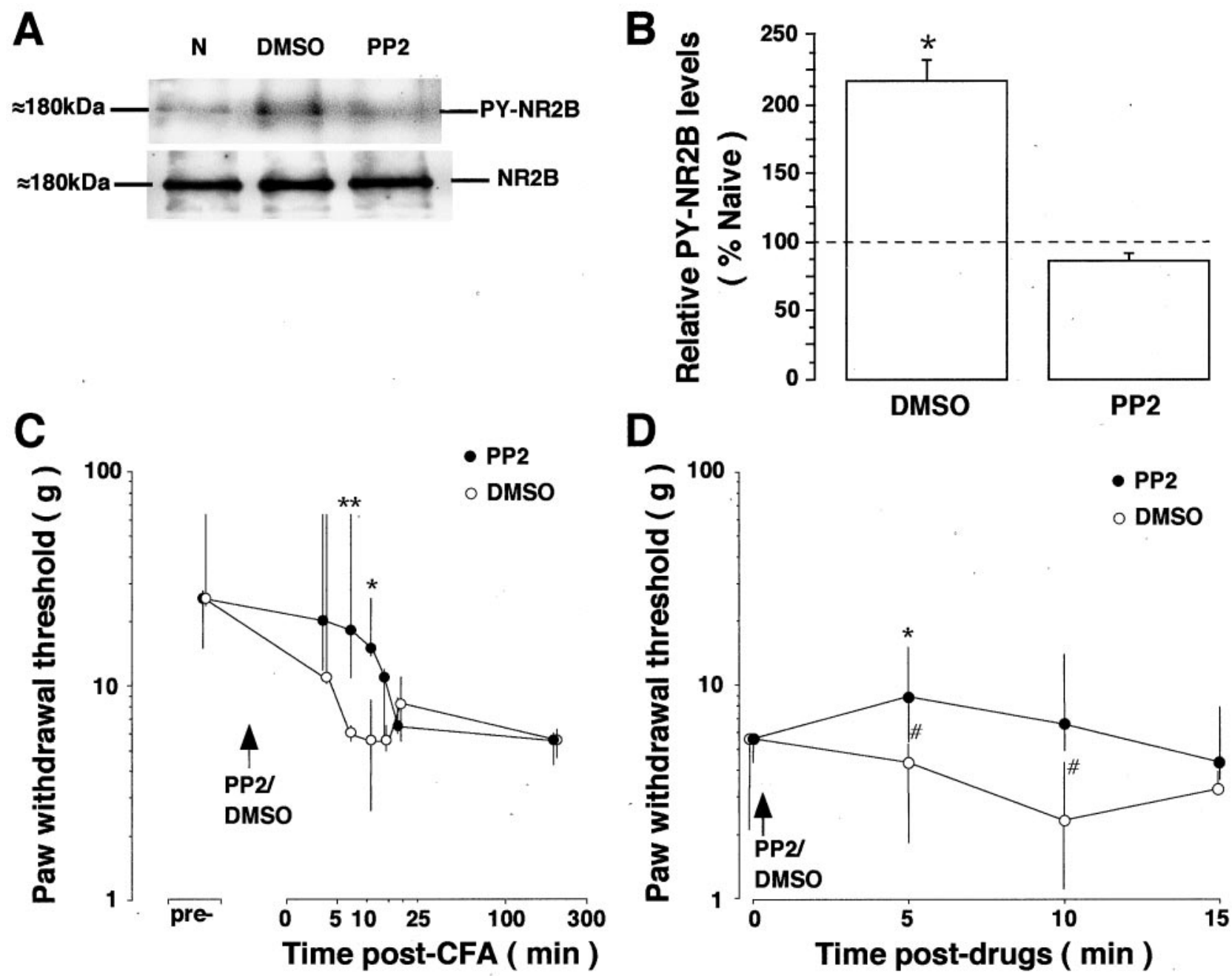

Figure 6. Effect of a selective Src family tyrosine kinase inhibitor, PP2, on tyrosine phosphorylation of NR2B and mechanical allodynia after inflammation. A, Representative immunoblots against anti-4G-10 (top) and NR2B (bottom) antibodies. PP2 (0.003 mg) was injected intrathecally 10 min before injection of CFA. The drug vehicle DMSO $(0.01 \mathrm{ml})$ was used as a control. $B$, Mean relative levels of tyrosine-phosphorylated NR2B proteins from three individual experiments. ${ }^{*} p<0.05$ versus naive rats. Dashed line indicates the control level. $C$, CFA-induced reduction of mechanical response threshold was attenuated by PP2 (0.003 mg, i.t.; $n=5)$ pretreatment at $10 \mathrm{~min}$ before injection of CFA. The von Frey threshold of the inflamed paw is shown by filled circles (PP2-treated) and open circles (DMSO-treated). Data are presented as median with interquartile ranges (75 percentile, upward bars; 25 percentile, downward bars). Note a delayed reduction of paw withdrawal threshold in rats receiving PP2. The effect of PP2 lasted $\sim 20$ min. * $p<0.05$; ${ }^{* *} p<0.01$; DMSO versus PP2. $D$, Effect of PP2 post-treatment on mechanical hyperalgesia and allodynia. At 5 hr after CFA injection, rats received intrathecal PP2 (0.003 mg; $n=8)$ or DMSO $(0.01 \mathrm{ml} ; n=7)$. There was an increase in mechanical response threshold at 5 min after PP2 injection. * $p<$ 0.05 versus pre-PP2 group; $\# p<0.05$, PP2 versus DMSO groups.

crease in NR2B tyrosine phosphorylation was blocked by pretreatment with chelerythrine (384 ng; $n=3$ ), a selective PKC inhibitor (Fig. 7).

\section{DISCUSSION}

The present study demonstrates that the development of hindpaw inflammation and hyperalgesia is associated with a rapid and prolonged enhancement of tyrosine phosphorylation of NR2B subunits of the NMDA receptor in the rat spinal cord. The increase in tyrosine phosphorylation occurred as early as $2-5 \mathrm{~min}$ after injection of the inflammatory agent and was sustained for a week. Although both NR2A and NR2B subunits can be tyrosinephosphorylated in vitro (Lau and Huganir, 1995; Christie et al., 1999), studies have shown that the NR2B, but not the NR2A subunit, exhibits increased tyrosine phosphorylation after 6-OHdopamine lesions of nigrostriatal neurons (Menegoz et al., 1995), BDNF treatment of cortical and hippocampal postsynaptic den- sities (Lin et al., 1998); and LTP (Rosenblum et al., 1996; Rostas et al., 1996). Complementing these earlier studies in reduced model systems, we show for the first time in an in vivo model of behavioral hyperalgesia and allodynia that the enhanced tyrosine phosphorylation of the NR2B subunit of the NMDA receptor may contribute to nociceptor activity-induced spinal plasticity and the development of central sensitization and persistent pain.

Our analyses indicate that the development and maintenance of NR2B tyrosine phosphorylation is dependent on primary afferent drive to the spinal cord. The time course of tyrosine phosphorylation was closely related to (1) the persistence of peripheral noxious stimulation, (2) the early development of hyperalgesia and allodynia, and (3) stimulus-induced plasma extravasation. The injection of CFA produced an effect on NR2B tyrosine phosphorylation that lasted for days. Because the nociceptive input produced by saline injection is primarily associated 


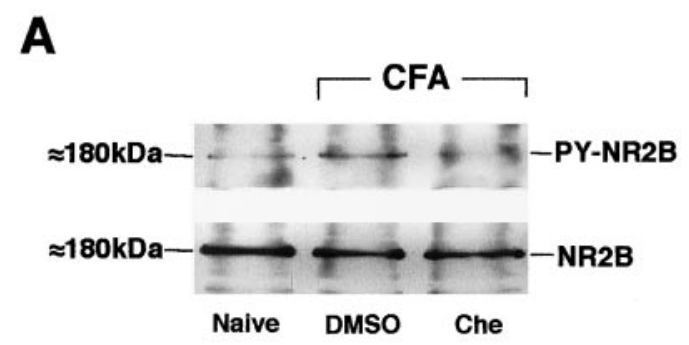

B

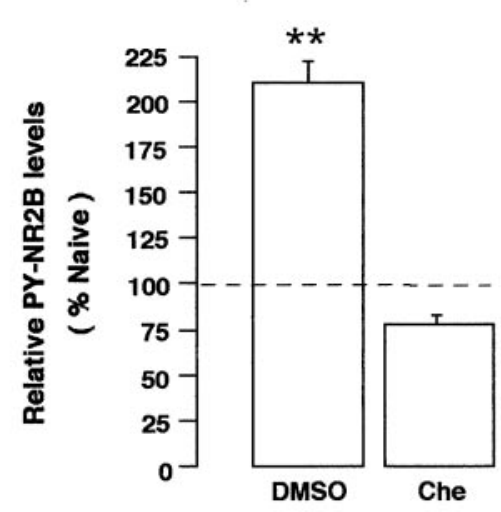

Figure 7. The effect of a PKC inhibitor, chelerythrine, on inflammationinduced tyrosine phosphorylation of NR2B. Chelerythrine (Che, $384 \mathrm{ng}$; $n=3$ per time point) was injected intrathecally $10 \mathrm{~min}$ before injection of CFA. The drug vehicle DMSO $(0.01 \mathrm{ml})$ was used as a control. $C$, Representative immunoblots against anti-4G-10 (PY-NR2B) and antiNR2B (bottom) antibodies. D, Mean relative levels of tyrosinephosphorylated NR2B proteins. The tyrosine phosphorylation of NR2B was blocked by chelerythrine pretreatment. Dashed line in $B$ indicates the control level. ${ }^{* *} p<0.01$ versus naive rats.

with the injection procedure per se, there was only a rapid and transient upregulation of NR2B tyrosine phosphorylation and a transient reduction of mechanical threshold that lasted for $10 \mathrm{~min}$ after saline injection. Mustard oil-induced NR2B tyrosine phosphorylation also paralleled and outlasted the Evans' blue extravasation produced by this stimulant.

Direct evidence of the importance of peripheral afferent drive was shown by local anesthesia of the injured area with lidocaine, which blocked upregulation of the NR2B tyrosine phosphorylation. The duration of blockage of NR2B tyrosine phosphorylation corresponded with the effective period of lidocaine, as suggested by our behavioral analysis (Fig. 4). Interestingly, the enhanced NR2B tyrosine phosphorylation reappeared after the block by lidocaine. Buritova et al. (1996) have shown that intraplantar infiltration with lignocaine and bupivacaine before carrageenan transiently limited signs of inflammatory pain, consistent with our findings. Our observations produce new evidence that inflammation-induced NR2B tyrosine phosphorylation is not only initiated, but also maintained by primary afferent input, and confirm previous suggestions that inflammatory hyperalgesia and altered central nociceptive processing are initiated and dynamically maintained by input from the site of injury (Gracely et al., 1992). Enhanced tyrosine phosphorylation of the NR2B was also observed in LTP (Rostas et al., 1996). However, the increase in NR2B tyrosine phosphorylation was not involved in the initiation of LTP because the increased tyrosine phosphorylation was only observed after LTP induction (Rosenblum et al., 1996; Rostas et al., 1996).
The NMDA receptor forms multiprotein complexes with postsynaptic density proteins including receptors, adaptor proteins, and protein kinases (Fujita and Kurachi, 2000). Interestingly, mGluRs are coupled with NMDA receptors in the postsynaptic density via several proteins such as homer, shank, and PSD-95 (Tu et al., 1999). This protein scaffold allows for efficient intracellular signaling. In fact, the NR2B subunit may be phosphorylated by kinases intrinsic to the postsynaptic density. After receiving strong primary afferent drive generated from peripheral nociceptors by inflammation, a cascade of events in the postsynaptic density of spinal neurons may lead to NR2B tyrosine phosphorylation. At least two major effects are expected after tyrosine phosphorylation of the NR2B subunits: (1) an increase in NMDA receptor channel current (Wang and Salter, 1994) and/or (2) the activation of the RAS-GTP-MAP kinase pathway through phosphotyrosine-bound adaptor proteins (Chen et al., 1998). This signal cascade related to tyrosine phosphorylation is primarily based on observations from in vitro studies. Whether it is applicable to injury-induced spinal plasticity is unclear. Our results linking tyrosine phosphorylation of the NMDA receptor to the development of inflammation and hyperalgesia provide a model system to assess in vivo the signal transduction pathways involved in spinal cord LTP or central sensitization.

Our results also suggest the upstream input that leads to NR2B tyrosine phosphorylation. The kinases that phosphorylate the NR2B subunits belong to the family of Src protein tyrosine kinases (for review, see Chen and Leonard, 1996; Ali and Salter, 2001). The finding that the inflammation-induced increase in NR2B tyrosine phosphorylation was abolished by genistein, a tyrosine kinase inhibitor, and PP2, an Src family protein tyrosine kinases inhibitor, is the first direct evidence that Src family tyrosine kinases participate in NR2B subunit receptor phosphorylation after activity-dependent plasticity in the spinal cord or other model systems (Ali and Salter, 2001). Importantly, we showed that intrathecal administration of PP2 before injection of CFA delayed the onset of mechanical hyperalgesia and allodynia. Genistein has been shown to attenuate inflammatory hyperalgesia (Lu et al., 2000b). Post-treatment of PP2 also blocked NR2B tyrosine phosphorylation and inflammatory hyperalgesia, suggesting that $\mathrm{NR} 2 \mathrm{~B}$ phosphorylation plays a role in maintaining central hyperexcitability. However, because post-treatment of PP2 only produced a small and transient effect, the Src activation may play a lesser role in maintaining central hyperexcitability. Although these correlative findings support our hypothesis that NR2B tyrosine phosphorylation is involved in the development of spinal plasticity and hyperalgesia after inflammation, direct evidence on a causal role of NR2B tyrosine phorphorylation to the inflammatory hyperlagesia is still missing. Recent studies have identified seven specific tyrosine residues on the $\mathrm{C}$ terminus of the NR2B subunit that are phosphorylated by Fyn, an Src family tyrosine kinase, in vitro (Nakazawa et al., 2001). Among those tyrosines, Tyr-1472 appears to be the major Fyn-mediated phosphorylation site, and Tyr-1472 phosphorylation is enhanced after induction of LTP in mouse hippocampal slices (Nakazawa et al., 2001). It would be very interesting to determine whether a deletion of the specific tyrosine site on the NR2B subunit will affect the development of CFA-induced hyperalgesia.

The Src family protein tyrosine kinases are activated by the PYK2-CAK $\beta$ pathway (Dikic et al., 1996), which is sensitive to an increase in intracellular calcium (for review, see Girault et al., 1999). One potential source of the increase in intracellular $\mathrm{Ca}^{2+}$ in spinal neurons after inflammation is through activation of 
G-protein-coupled receptors such as metabotropic glutamate receptors (mGluRs) and NK1 tachykinin receptors. We provided evidence that intrathecal administration of a group I mGluR antagonist blocked inflammation-induced NR2B tyrosine phosphorylation, thus supporting the involvement of mGluRs. This effect should be attributed to the blockage of postsynaptic mGluRs and its interaction with ionotropic GluRs but not presynaptic modulation. Although mGluRs are present in presynaptic terminals, the activation of presynaptic mGluRs functions to reduce presynaptic glutamate release (for review, see Pin and Duvoisin, 1995). In addition, intrathecal administration of an NK1 receptor antagonist also attenuated NR2B tyrosine phosphorylation. These results are consistent with our hypothesis and demonstrate in vivo a role for interactions between G-proteincoupled receptors and ionotropic glutamate receptors in the development of spinal plasticity. The application of group I mGluR antagonists have been shown to reduce spinothalamic neuronal activity and mechanical allodynia (Neugebauer et al., 1999; Mills et al., 2000). Also, antisense ablation of $\mathrm{mGluR}_{1}$ inhibits spinal nociceptive transmission (Young et al., 1998). Activation of mGluRs potentiates NMDA responses (Aniksztejn et al., 1991; Cerne and Randic, 1992; Kelso et al., 1992), produces mechanical hyperalgesia (Meller et al., 1993), and is necessary for NMDA-induced LTP (O'Connor et al., 1995). Previous studies have also suggested an interaction between spinal NMDA and $\mathrm{NK}_{1}$ tachykinin receptor systems during the processing of nociceptive information (Dougherty and Willis, 1991; Seguin and Millan, 1994; Marvizón et al., 1997). In summary, these results indicate that G-protein-coupled receptors and subsequent phospholipase $\mathrm{C}$ activation contribute to NR2B tyrosine phosphorylation and are a potential source of intracellular $\mathrm{Ca}^{2+}$ release necessary for activation of kinases involved in spinal plasticity and central sensitization. Alternatively, calcium may enter the cell through voltage-gated calcium channels, calcium-permeable AMPA receptor channels, and NMDA receptor channels.

Protein kinase $\mathrm{C}$ is known to potentiate NMDA receptor activation (Chen and Huang, 1992; Kelso et al., 1992; Zheng et al., 1999). PKC may stimulate Src through the PYK2-CAK $\beta$ pathway (for review, see Ali and Salter, 2001) and induces NR2 tyrosine phosphorylation in the rat hippocampus (Grosshans and Browning, 2001). Our results showed that the enhanced NR2B tyrosine phosphorylation was blocked by a PKC inhibitor, confirming the involvement of PKC in this effect. Taken together, our findings suggest that signal transduction upstream to NR2B tyrosine phosphorylation involves G-protein-coupled receptors, PKC and Src family protein tyrosine kinases (Lu et al., 1999). Future studies will need to delineate the transduction pathway or pathways involved in this cascade.

\section{REFERENCES}

Ali DW, Salter MW (2001) NMDA receptor regulation by Src kinase signalling in excitatory synaptic transmission and plasticity. Curr Opin Neurobiol 11:336-342.

Aniksztejn L, Bregestovski P, Ben-Ari Y (1991) Selective activation of quisqualate metabotropic receptor potentiates NMDA but not AMPA responses. Eur J Pharmacol 205:327-328.

Boyce S, Wyatt A, Webb JK, O’Donnell R, Mason G, Rigby M, Sirinathsinghji D, Hill RG, Rupniak NM (1999) Selective NMDA NR2B antagonists induce antinociception without motor dysfunction: correlation with restricted localisation of NR2B subunit in dorsal horn. Neuropharmacology 38:611-623.

Buritova J, Fletcher D, Honoré P, Besson J-M (1996) Effects of local anaesthetics on carrageenan-evoked inflammatory nociceptive processing in the rat. Br J Anaesth 77:645-652.

Cerne R, Randic M (1992) Modulation of AMPA and NMDA responses in rat spinal dorsal horn neurons by trans-1-aminocyclopentane-1, 3-dicarboxylic acid. Neurosci Lett 144:180-184.

Chen C, Leonard JP (1996) Protein tyrosine kinase-mediated potentiation of currents from cloned NMDA receptors. $J$ Neurochem 67:194-200.

Chen HJ, Rojas-Soto M, Oguni A, Kennedy MB (1998) A synaptic Ras-GTPase activating protein (p135 SynGAP) inhibited by CaM kinase II. Neuron 20:895-904.

Chen L, Huang LY (1992) Protein kinase C reduces $\mathrm{Mg}^{2+}$ block of NMDA-receptor channels as a mechanism of modulation. Nature 356:521-523.

Christie JM, Wenthold RJ, Monaghan DT (1999) Insulin causes a transient tyrosine phosphorylation of NR2A and NR2B NMDA receptor subunits in rat hippocampus. J Neurochem 72:1523-1528.

De Biasi S, Rustioni A (1988) Glutamate and substance P coexist in primary afferent terminals in the superficial laminae of spinal cord. Proc Natl Acad Sci USA 85:7820-7824.

Dikic I, Tokiwa G, Lev S, Courtneidge SA, Schlessinger J (1996) A role for Pyk2 and Src in linking G-protein-coupled receptors with MAP kinase activation. Nature 383:547-550.

Dougherty PM, Willis WD (1991) Enhancement of spinothalamic neuron responses to chemical and mechanical stimuli following combined micro-iontophoretic application of $N$-methyl-D-aspartic acid and substance P. Pain 47:85-93.

Dubner R, Ruda MA (1992) Activity-dependent neuronal plasticity following tissue injury and inflammation. Trends Neurosci 15:96-103.

Dunah AW, Wang Y, Yasuda RP, Kameyama K, Huganir RL, Wolfe BB Standaert DG (2000) Alterations in subunit expression, composition, and phosphorylation of striatal $N$-methyl-D-aspartate glutamate receptors in a rat 6-hydroxydopamine model of Parkinson's disease. Mol Pharmacol 57:342-352.

Fujita A, Kurachi Y (2000) SAP family proteins. Biochem Biophys Res Commun 269:1-6.

Girault JA, Costa A, Derkinderen P, Studler JM, Toutant M (1999) FAK and PYK2/CAKbeta in the nervous system: a link between neuronal activity, plasticity and survival? Trends Neurosci 22:257-263.

Gracely RH, Lynch SA, Bennett GJ (1992) Painful neuropathy: altered central processing maintained dynamically by peripheral input. Pain 51:175-194.

Grosshans DR, Browning MD (2001) Protein kinase C activation induces tyrosine phosphorylation of the NR2A and NR2B subunits of the NMDA receptor. J Neurochem 76:737-744.

Guo W, Guan Y, Zou S-P, Dubner R, Ren K (2001) Tyrosine phosphorylation (tyr-P) of the NR2B subunit of the NMDA receptor in the rat spinal cord after inflammation. Soc Neurosci Abstr 27:138.

Haley JE, Sullivan AF, Dickenson AH (1990) Evidence of spinal $N$-methyl-D-aspartate receptor involvement in prolonged chemical nociception in the rat. Brain Res 518:218-226.

Hargreaves K, Dubner R, Brown F, Flores C, Joris J (1988) A new and sensitive method for measuring thermal nociception in cutaneous hyperalgesia. Pain 32:77-88.

Hylden JLK, Nahin RL, Traub RJ, Dubner R (1989) Expansion of receptive fields of spinal lamina I projection neurons in rats with unilateral adjuvant-induced inflammation: the contribution of dorsal horn mechanisms. Pain 37:229-243.

Iadarola MJ, Brady LS, Draisci G, Dubner R (1988) Enhancement of dynorphin gene expression in spinal cord following experimental inflammation: stimulus specificity, behavioral parameters and opioid receptor binding. Pain 35:313-326.

Imbe H, Iwata K, Zhou Q-Q, Zou S, Dubner R, Ren K (2001) Orofacial deep and cutaneous tissue inflammation and trigeminal neuronal activation: Implications for persistent temporomandibular pain. Cells Tissues Organs 169:238-247.

Ji RR, Befort K, Brenner GJ, Woolf CJ (2002) ERK MAP kinase activation in superficial spinal cord neurons induces prodynorphin and NK-1 upregulation and contributes to persistent inflammatory pain hypersensitivity. J Neurosci 22:478-485.

Kelso SR, Nelson TE, Leonard JP (1992) Protein kinase C-mediated enhancement of NMDA currents by metabotropic glutamate receptors in Xenopus oocytes. J Physiol (Lond) 449:705-718.

Lau LF, Huganir RL (1995) Differential tyrosine phosphorylation of $N$-methyl-D-aspartate receptor subunits. J Biol Chem 270:20036-20041.

Laube B, Kuhse J, Betz H (1998) Evidence for a tetrameric structure of recombinant NMDA receptors. J Neurosci 18:2954-2961.

Lin SY, Wu K, Levine ES, Mount HT, Suen PC, Black IB (1998) BDNF acutely increases tyrosine phosphorylation of the NMDA receptor subunit $2 \mathrm{~B}$ in cortical and hippocampal postsynaptic densities. Brain Res Mol Brain Res 55:20-27.

Lu WY, Xiong ZG, Lei S, Orser BA, Dudek E, Browning MD, MacDonald JF (1999) G-protein-coupled receptors act via protein kinase $\mathrm{C}$ and Src to regulate NMDA receptors. Nat Neurosci 2:331-338.

Lu WY, Jackson MF, Bai D, Orser BA, MacDonald JF (2000a) In CA1 pyramidal neurons of the hippocampus protein kinase $\mathrm{C}$ regulates calciumdependent inactivation of NMDA receptors. J Neurosci 20:4452-4461.

Lu WY, Zhang LP, Salter MW, Westlund KN (2000b) Tyrosine kinase 
inhibitors prevent development of secondary hyperalgesia in carrageenaninduced arthritic rats. Soc Neurosci Abstr 26:1692.

Malenka RC, Nicoll RA (1999) Long-term potentiation-a decade of progress? Science 285:1870-1874.

Marvizón JC, Martinez V, Grady EF, Bunnett NW, Mayer EA (1997) Neurokinin 1 receptor internalization in spinal cord slices induced by dorsal root stimulation is mediated by NMDA receptors. J Neurosci 17:8129-8136.

Meller ST, Dykstra CL, Gebhart GF (1993) Acute mechanical hyperalgesia is produced by coactivation of AMPA and metabotropic glutamate receptors. NeuroReport 4:879-882.

Menegoz M, Lau LF, Herve D, Huganir RL, Girault JA (1995) Tyrosine phosphorylation of NMDA receptor in rat striatum: effects of 6-OH-dopamine lesions. NeuroReport 7:125-128.

Mills CD, Xu GY, Johnson KM, McAdoo DJ, Hulsebosch CE (2000) AIDA reduces glutamate release and attenuates mechanical allodynia after spinal cord injury. NeuroReport 11:3067-3070.

Moon IS, Apperson ML, Kennedy MB (1994) The major tyrosinephosphorylated protein in the postsynaptic density fraction is $N$-methylD-aspartate receptor subunit 2B. Proc Natl Acad Sci USA 91:3954-3958.

Nakazawa T, Komai S, Tezuka T, Hisatsune C, Umemori H, Semba K, Mishina M, Manabe T, Yamamoto T (2001) Characterization of Fynmediated tyrosine phosphorylation sites on GluR epsilon 2 (NR2B) subunit of the $N$-methyl-D-aspartate receptor. J Biol Chem 276:693-699.

Neugebauer V, Chen PS, Willis WD (1999) Role of metabotropic glutamate receptor subtype mGluR1 in brief nociception and central sensitization of primate STT cells. J Neurophysiol 82:272-282.

O'Connor JJ, Rowan MJ, Anwyl R (1995) Tetanically induced LTP involves a similar increase in the AMPA and NMDA receptor components of the excitatory postsynaptic current: investigations of the involvement of mGlu receptors. J Neurosci 15:2013-2020.

Pin JP, Duvoisin R (1995) The metabotropic glutamate receptors: structure and functions. Neuropharmacology 34:1-26.

Ren K (1999) An improved method for assessing mechanical allodynia in the rat. Physiol Behav 67:711-716.

Ren K, Hylden JLK, Williams GM, Ruda MA, Dubner R (1992) The effects of a non-competitive NMDA receptor antagonist, MK-801, on behavioral hyperalgesia and dorsal horn neuronal activity in rats with unilateral inflammation. Pain 50:331-344.

Rosenblum K, Dudai Y, Richter-Levin G (1996) Long-term potentiation increases tyrosine phosphorylation of the $N$-methyl-D-aspartate receptor subunit $2 \mathrm{~B}$ in rat dentate gyrus in vivo. Proc Natl Acad Sci USA 93:10457-10460.

Ross CA, Wright GE, Resh MD, Pearson RC, Snyder SH (1988) Brainspecific src oncogene mRNA mapped in rat brain by in situ hybridization. Proc Natl Acad Sci USA 85:9831-9835.

Rostas JA, Brent VA, Voss K, Errington ML, Bliss TV, Gurd JW (1996) Enhanced tyrosine phosphorylation of the $2 \mathrm{~B}$ subunit of the $N$-methylD-aspartate receptor in long-term potentiation. Proc Natl Acad Sci USA 93:10452-10456.

Seguin L, Millan MJ (1994) The glycine B receptor partial agonist, (+)HA966, enhances induction of antinociception by RP67580 and CP-99, 994. Eur J Pharmacol 253:R1-R3.

Skeberdis VA, Lan J, Opitz T, Zheng X, Bennett MV, Zukin RS (2001) mGluR1-mediated potentiation of NMDA receptors involves a rise in intracellular calcium and activation of protein kinase C. Neuropharmacology 40:856-865.

Sluka KA, Jordan HH, Willis WD, Westlund KN (1994) Differential effects of $N$-methyl-D-aspartate (NMDA) and non-NMDA receptor antagonists on spinal release of amino acids after development of acute arthritis in rats. Brain Res 664:77-84.

Tingley WG, Ehlers MD, Kameyama K, Doherty C, Ptak JB, Riley CT, Huganir RL (1997) Characterization of protein kinase A and protein kinase C phosphorylation of the $N$-methyl-D-aspartate receptor NR1 subunit using phosphorylation site-specific antibodies. J Biol Chem 272:5157-5166

Tu JC, Xiao B, Naisbitt S, Yuan JP, Petralia RS, Brakeman P, Doan A, Aakalu VK, Lanahan AA, Sheng M, Worley PF (1999) Coupling of mGluR/Homer and PSD-95 complexes by the Shank family of postsynaptic density proteins. Neuron 23:583-592.

Urban MO, Jiang MC, Gebhart GF (1996) Participation of central descending nociceptive facilitatory systems in secondary hyperalgesia produced by mustard oil. Brain Res 737:83-91.

Van Arman CG, Begany AJ, Miller LM, Pless HH (1965) Some details of the inflammations caused by yeast and carrageenin. J Pharmacol Exp Ther 150:328-334.

Wang YT, Salter MW (1994) Regulation of NMDA receptors by tyrosine kinases and phosphatases. Nature 369:233-235.

Woolf CJ, King AE (1990) Dynamic alterations in the cutaneous mechanoreceptive fields of dorsal horn neurons in the rat spinal cord. J Neurosci 10:2717-2726.

Woolf CJ, Salter MW (2000) Neuronal plasticity: increasing the gain in pain. Science 288:1765-1768.

Woolf CJ, Thompson SWN (1991) The induction and maintenance of central sensitization is dependent on $N$-methyl-D-aspartic acid receptor activation; implications for the treatment of post-injury pain hypersensitivity states. Pain 44:293-299.

Xiong ZG, Pelkey KA, Lu WY, Lu YM, Roder JC, MacDonald JF, Salter MW (1999) Src potentiation of NMDA receptors in hippocampal and spinal neurons is not mediated by reducing zinc inhibition. J Neurosci 19:RC37(1-6)

Yaksh TL, Rudy TA (1976) Chronic catheterization of the spinal subarachnoid space. Physiol Behav 17:1031-1036.

Young MR, Blackburn-Munro G, Dickinson T, Johnson MJ, Anderson H, Nakalembe I, Fleetwood-Walker SM (1998) Antisense ablation of type I metabotropic glutamate receptor mGluR1 inhibits spinal nociceptive transmission. J Neurosci 18:10180-10188.

Yu XM, Askalan R, Keil II GJ, Salter MW (1997) NMDA channel regulation by channel-associated protein tyrosine kinase Src. Science 275:674-678.

Yung KK (1998) Localization of glutamate receptors in dorsal horn of rat spinal cord. NeuroReport 9:1639-1644.

Zheng X, Zhang L, Wang AP, Bennett MV, Zukin RS (1999) Protein kinase $\mathrm{C}$ potentiation of $N$-methyl-D-aspartate receptor activity is not mediated by phosphorylation of $N$-methyl-D-aspartate receptor subunits. Proc Natl Acad Sci USA 96:15262-15267.

Zou X, Lin Q, Willis WD (2000) Enhanced phosphorylation of NMDA receptor 1 subunits in spinal cord dorsal horn and spinothalamic tract neurons after intradermal injection of capsaicin in rats. $\mathrm{J}$ Neurosci 20:6989-6997. 